\title{
PENGEMBANGAN BAHAN AJAR PERKEMBANGAN ANAK USIA SD SEBAGAI SARANA BELAJAR MANDIRI MAHASISWA
}

\author{
Kasina Ahmad \\ Ika Lestari
}

\begin{abstract}
Instructional material is one of teh important learning resources in teaching and learning process. However, the course of The Development of Primary School Age Children at the Department of Primary School Teacher Education, School of Education, State University of Jakarta, has not a reference which can be used as a main text book. This research, therefore, developed a text book to meet the need. Applying research and development method introduce by Borg and Gal and tried out, this research has produce a main text book that has proved a high readability and signifiacnt to the course. It was also found out that the text book produce is able to motivate the students to learn and has improved the students' learning achievement.
\end{abstract}

Keywords :instructional materials, text book, readability, independent learning.

Abstrak

Bahan ajar sebagai salah satu sumber belajar, saat ini, memiliki peran penting dalam proses pembelajaran. Kendala dalam mata kuliah Perkembangan Anak Usia SD yaitu menemukan sebuah buku sumber yang khusus membahas mengenai perkembangan Anak Usia SD. Penelitian ini berusaha untuk mengurangi kendala tersebut dengan menghadirkan sebuah bahan ajar yang telah terbukti validitas dan reliabilitasnya sehingga dapat digunakan sebagai sumber belajar mahasiswa di perguruan tinggi PGSD FIP UNJ. Penelitian ini dilaksanakan di jurusan PGSD FIP UNJ untuk mahasiswa yang mengikuti mata kuliah Perkembangan Anak Usia SD, sebanyak 48 mahasiswa. Metode penelitian yang digunakan dalam penelitian ini adalah R \& D dari Borg dan Gall yang melibatkan dua instrumen yaitu data cloze test dan tes pilihan ganda. Penelitian ini menemukan tingkat keterbacaan dari bahan ajar mata kuliah Perkembangan Anak Usia SD cukup tinggi yang berarti bahan ajar mudah dipahami mahasiswa. Selain itu, penguasaan isi bahan ajar oleh mahasiswa adalah baik. Diharapkan bahwa hasil studi ini dapat menjadi salah satu rujukan untuk penelitian lebih lanjut.

Kata-kata kunci: bahan ajar, buku teks pelajaran, keterbacaan, belajar mandiri

\section{PENDAHULUAN}

\section{Latar Belakang Masalah}

Perkembangan IPTEK turut menuntut pendidik untuk selalu kreatif dalam mewujudkan hasil belajar peserta didik yang optimal. Dampak perkembangan IPTEK terhadap proses pembelajaran adalah diperkayanya sumber dan media pembelajaran, seperti buku teks, modul, overhead transparansi, film, video, televisi, slide, hypertext, web, dan sebagainya.

Bahan ajar adalah sumber belajar yang sampai saat ini memiliki peranan penting untuk menunjang proses pembelajaran. Bahan ajar sebaiknya mampu memenuhi syarat sebagai bahan pembelajaran karena banyak bahan-bahan ajar yang digunakan di dalam kegiatan pembelajaran, umumnya cenderung berisikan informasi bidang studi saja dan tidak terorganisasi dengan baik. Kualitas bahan ajar yang rendah dengan pembelajaran konvensional akan berakibat rendahnya perolehan prestasi belajar peserta didik.

Selain itu, pergeseran pendidik yang awalnya sebagai sumber belajar satu-satunya dan saat ini mengarah sebagai fasilitator peserta didik menuntut kehadiran sebuah bahan ajar/buku pegangan agar menjembatani permasalahan keterbatasan kemampuan daya serap peserta didik dan keterbatasan kemampuan pendidik dalam proses belajar mengajar di kelas. Kehadiran bahan ajar bisa untuk memahami dan memberikan perlakuan sesuai dengan 
karakteristik peserta didik secara individual, menjembatani persoalan rendahnya aktualisasi diri peserta didik, sehingga materi-materi yang kurang dipahami dapat diekplorasi kembali melalui bahan ajar cetak.

Hal ini sejalan dengan penelitian yang dilakukan oleh Endang Sunarsih yang berjudul "Pengaruh Penggunaan Bahan Ajar Modul Terhadap Prestasi Belajar Siswa Pada Pembelajaran Akuntansi Kelas X1 IPS MAN Malang 1". Tujuan dari penelitian ini adalah untuk mengetahui apakah prestasi belajar belajar siswa dengan menggunakan bahan ajar modul lebih baik dari prestasi belajar siswa yang diajar dengan pembelajaran konvensional. Hasil penelitian menunjukkan bahwa prestasi belajar akuntansi siswa yang belajar dengan menggunakan bahan ajar modul lebih baik dibandingkan dengan siswa yang belajar dengan pembelajaran konvensional (Sunarsih, 2009).

Bahan ajar dapat dibuat dengan berbagai bentuk antara lain bahan ajar yang ditulis dalam bentuk buku seperti modul dan bahan ajar yang ditampilkan ke dalam media audio visual melalui jaringan internet dan atau intranet. Dalam penelitian ini, maksud dari bahan ajar adalah modul.

Perkembangan Anak Usia SD merupakan mata kuliah yang diberikan untuk mahasiswa PGSD FIP UNJ. Mata kuliah Perkembangan Anak Usia SD menyajikan perkembangan anak SD dilihat dari perkembangan bahasa, kognitif, moral dan sosial serta prinsip-prinsip dan karakteristik perkembangan anak SD. Dengan demikian, mahasiswa diajak untuk lebih peka dan sadar betapa kompleksnya siswa SD sehingga diharapkan ketika mahasiswa menyelesaikan mata kuliah Perkembangan Anak Usia SD diharapkan dapat memahami permasalahanpermasalahan pada siswa SD serta membantu mencari pemecahan masalahnya bertumpu pada aspek-aspek perkembangan yang dialami siswa SD.

Berdasarkan hasil wawancara peneliti dengan para mahasiswa PGSD FIP UNJ mata kuliah Perkembangan Anak Usia SD, ditemukan sebuah kendala dalam menemukan sebuah buku sumber yang khusus membahas mengenai perkembangan anak usia SD. Buku-buku yang banyak beredar di pasaran lebih banyak merujuk pada perkembangan usia remaja dan sekalipun ada, biasanya masa usia SD hanya dibahas untuk 1-3 bab saja sehingga belum terlihat jelas relevansinya dalam pembelajaran SD.

Selain itu, kendala yang dihadapi adalah banyaknya materi yang membutuhkan ingatan/ hapalan dalam mata kuliah Perkembangan Anak Usia SD menyebabkan motivasi belajar mahasiswa rendah.
Oleh karena itu, maka penelitian ini berusaha untuk membuat bahan ajar untuk mata kuliah Perkembangan Anak Usia SD dengan bahasa serta ilustrasi materi yang dibuat agar mudah dipahami oleh mahasiswa untuk meningkatkan motivasi belajar dan keaktifan mahasiswa dalam pembelajaran, bisa belajar mandiri tanpa perlu bergantung pada kehadiran dosen di kelas sehingga hasil belajar pun meningkat.

Dengan deskripsi mata kuliah di atas, dapat dilihat bahwa pentingnya kehadiran bahan ajar cetak untuk mendampingi mahasiswa dalam mempelajari kedua mata kuliah tersebut dan sekaligus sebagai sarana belajar mandiri sehingga mahasiswa dapat belajar sesuai dengan kemampuan daya serap maupun karakteristiknya. Oleh karena itu, dipandang perlu untuk mengembangkan sebuah bahan ajar bagi mata kuliah Perkembangan Anak Usia SD dalam meningkatkan kualitas proses belajar mahasiswa.

\section{Rumusan Masalah}

Berdasarkan latar belakang masalah di atas, maka perumusan masalah dalam penelitian ini adalah bagaimana mengembangkan bahan ajar cetak mata kuliah Perkembangan Anak Usia SD sebagai sarana belajar mandiri mahasiswa jurusan PGSD FIP UNJ? Tujuan

Penelitian ini bertujuan untuk mendapatkan bahan ajar cetak mata kuliah Perkembangan Anak Usia SD yang telah teruji validitas maupun reliabilitasnya sehingga dapat digunakan sebagai salah satu sumber belajar dalam perkuliahan mahasiswa PGSD FIP UNJ.

\section{KAJIAN PUSTAKA}

\section{Hakikat Bahan Ajar}

Bahan ajar adalah seperangkat sarana atau alat pembelajaran yang berisikan materi pembelajaran, metode, batasan-batasan, dan cara mengevaluasi yang didesain secara sistematis dan menarik dalam rangka mencapai tujuan yang diharapkan, yaitu mencapai kompetensi atau subkompetensi dengan segala kompleksitasnya (Widodo \& Jasmadi, 2008: 40).

Pengertian di atas menggambarkan bahwa suatu bahan ajar hendaknya dirancang dan ditulis dengan kaidah instruksional karena akan digunakan oleh pendidik untuk membantu dan menunjang proses pembelajaran.

Menurut Sudrajat (2008: 1), bahan ajar adalah seperangkat materi yang disusun secara sistematis baik tertulis maupun tidak sehingga tercipta lingkungan/suasana yang memungkinkan siswa untuk belajar. Selain itu, bahan ajar juga merupakan 
seperangkat materi pelajaran (teaching-material) yang disusun secara sistematis, menampilkan sosok utuh dari kompetensi yang akan dikuasai peserta didik dalam kegiatan pembelajaran. Dengan bahan ajar memungkinkan peserta didik dapat mempelajari suatu kompetensi atau kompetensi dasar secara runtut dan sistematis sehingga secara akumulatif mampu menguasai semua kompetensi secara utuh dan terpadu.

Berdasarkan definisi-definisi di atas, maka dapat ditarik kesimpulan, dalam penelitian ini yang dimaksud dengan bahan ajar adalah seperangkat materi pelajaran yang mangacu pada kurikulum yang digunakan (dalam hal ini adalah silabus perkuliahan) dalam rangka mencapai standar kompetensi dan kompetensi dasar yang telah ditentukan.

Secara garis besar, fungsi bahan ajar bagi pendidik adalah untuk mengarahkan semua aktivitasnya dalam proses pembelajaran sekaligus merupakan substansi kompetensi seharusnya diajarkan kepada peserta didik. Sedangkan bagi peserta didik akan menjadi pedoman dalam proses pembelajaran dan merupakan substansi kompetensi yang seharusnya dipelajari.

Bahan ajar juga berfungsi sebagai alat evaluasi pencapaian hasil pembelajaran. Menurut Sudjana dan Riva'i (2003: 56-58). bahan ajar berfungsi sebagai berikut :

a) Pedoman bagi guru yang akan mengarahkan semua aktivitasnya dalam proses pembelajaran, sekaligus merupakan substansi kompetensi yang seharusnya diajarkan/dilatihkan kepada siswanya

b) Pedoman bagi siswa yang dapat mengarahkan semua aktivitasnya dalam proses pembelajaran, sekaligus merupakan substansi kompetensi yang seharusnya dipelajari/dikuasai oleh siswanya

c) Alat evaluasi pencapaian/penguasaan hasil pembelajaran.

Bahan ajar yang sering dijumpai antara lain bahan ajar cetak maupun bahan ajar noncetak. Bahan ajar cetak berupa hand out, buku, modul, dan brosur. Handout adalah pernyataan yang telah disiapkan oleh pembicara (Eriyadi, 2008: 1).

Buku sebagai bahan ajar merupakan sumber belajar yang berisi ilmu pengetahuan hasil analisis terhadap kurikulum dalam bentuk tertulis. Buku disusun dengan menggunakan bahasa sederhana, menarik, dilengkapi gambar, keterangan, isi buku, dan daftar pustaka. Buku akan sangat membantu guru dan siswa dalam mendalami ilmu pengetahuan sesuai dengan mata pelajaran masing-masing (Eriyadi, 2008: $1)$.
Modul merupakan bahan ajar yang ditulis dengan tujuan agar peserta didik dapat belajar secara mandiri tanpa atau dengan bimbingan guru, oleh karena itu modul harus berisi tentang petunjuk belajar, kompetensi yang akan dicapai, isi materi pelajaran, informasi pendukung, latihan soal, petunjuk kerja, evaluasi dan balikan terhadap hasil evaluasi (Eriyadi, 2008: 1).

Brosur merupakan bahan informasi tertulis mengenai suatu masalah yang disusun atas beberapa halaman dan dilipat tanpa dijilid. Brosur dapat menjadi bahan ajar yang menarik karena bentuknya praktis. Agar brosur tidak terlalu banyak sebaiknya hanya memuat satu kompetensi dasar saja. Ilustrasi dalam brosur akan menambah daya tarik siswa untuk menggunakannya (Eriyadi, 2008: 1).

Menurut Mulyasa (2006: 46-47), ada beberapa keunggulan dari bahan ajar berupa modul, sebagai berikut.

a) Berfokus pada kemampuan individual peserta didik, karena pada hakikatnya peserta didik memiliki kemampuan untuk bekerja sendiri dan lebih bertanggung jawab atas tindakantindakannya.

b) Adanya kontrol terhadap hasil belajar mengenai penggunaan standar kompetensi dalam setiap modul yang harus dicapai oleh peserta didik.

c) Relevansi kurikulum ditunjukkan dengan adanya tujuan dan cara pencapaiannya, sehingga peserta didik dapat mengetahui keterkaitan antara pembelajaran dan hasil yang akan diperolehnya.

Sedangkan keterbatasan dari penggunaan modul, sebagai berikut.

a) Penyusunan modul yang baik membutuhkan keahlian tertentu.

b) Sulit menentukan proses penjadwalan dan kelulusan, serta membutuhkan manajemen pendidikan yang sangat berbeda dari pembelajaran konvensional, karena setiap peserta didik menyelesaikan modul dalam waktu yang berbedabeda, bergantung pada kecepatan dan kemampuan masing-masing.

c) Dukungan pembelajaran berupa sumber belajar, pada umumnya cukup mahal, karena setiap peserta didik harus mencarinya sendiri (Mulyasa, 2006: 4647).

Bahan ajar (modul) memiliki beberapa karakteristik, yaitu self instructional, self contained, stand alone, adaptive, dan user friendly (Widodo \& Jasmadi, 2008: 50).

Pertama, selfinstructional yaitu bahan ajar dapat membuat peserta didik mampu membelajarkan diri 
sendiri dengan modul yang dikembangkan. Kedua, self contained yaitu seluruh materi pelajaran dari satu unit kompetensi atau subkompetensi yang dipelajari terdapat di dalam satu bahan ajar secara utuh. Ketiga, stand alone (berdiri sendiri) yaitu bahan ajar yang dikembangkan tidak tergantung pada bahan ajar lain atau tidak harus digunakan bersama-sama dengan bahan ajar lain. Keempat, adaptive yaitu bahan ajar hendaknya memiliki daya adaptif yang tinggi terhadap perkembangan ilmu dan teknologi. Kelima, user friendly yaitu setiap instruksi dan paparan informasi yang tampil bersifat membantu dan bersahabat dengan pemakainya, termasuk kemudahan pemakai dalam merespon, mengakses sesuai dengan keinginan (Widodo \& Jasmadi, 2008: 50).

\section{Pengembangan Bahan Ajar dengan Metode Research} and Development (R\&D)

Pengembangan bahan ajar baik untuk proses pembelajaran jarak jauh maupun langsung adanya tatap muka antara pendidik dengan peserta didik merupakan sebuah ciri dari sistem pembelajaran. Secara umum, pengembangan bahan ajar dapat dilakukan dengan tiga cara yaitu starting from scratch, text transformation, dan compilation (Widodo \& Jasmadi, 2008: 55).

Starting from scratch menunjukkan bahwa tim pengembang bahan ajar dapat menyusun sendiri sebuah bahan ajar yang akan digunakan dalam kegiatan pembelajaran karena tim pengembang dianggap terdiri dari para pakar dalam bidang ilmu terkait, mempunyai kemampuan menulis dan mengerti kebutuhan peserta didik. Selain itu, tim pengembang juga dianggap mempunyai kemampuan menulis bahan ajar sesuai dengan kaidah instruksional (Widodo \& Jasmadi, 2008: 55).

Text transformation menunjukkan bahwa tim pengembang bahan ajar mendapat kesempatan besar untuk memanfaatkan informasi-informasi yang telah ada (misalnya buku teks, artikel jurnal, internet, dan lain-lain) dalam menyusun bahan ajar (Widodo \& Jasmadi, 2008: 56).

Compilation menunjukkan bahwa bahan ajar bersumber dari berbagai sumber informasi, baik dari penelitian sendiri atau ditulis sendiri lalu digabungkan dengan informasi-informasi yang telah ada misalnya dari buku teks, jurnal ilmiah, artikel, informasi dari internet, dan lainnya tanpa memberikan perubahan pada informasi tersebut (Widodo \& Jasmadi, 2008: 57).

Berdasarkan ketiga hal tersebut, maka ciri dari bahan ajar pada penelitian ini yaitu masih berupa compilation.
Dalam penelitian ini, akan digunakan metode Research and Development (R\&D) dari Borg, W.R. dan Gall, M.D. sebagai tahap pengembangan bahan ajar cetak mata kuliah Perkembangan Anak Usia SD dan Filsafat Pendidikan berdasarkan pertimbangan kesesuaian dengan sifat penelitian yang mengarah pada belajar mandiri.

Borg dan Gall (dalam Ghufron, 2005) mengatakan "educational research and development $(R \mathcal{E}$ $D)$ is a process used to develop and validate educational production". Dengan pengertian tersebut maka serangkaian langkah penelitian dan pengembangan dilakukan secara siklus, yang mana pada setiap langkah yang akan dilalui atau dilakukan selalu mengacu pada hasil langkah sebelumnya hingga pada akhirnya diperoleh suatu produk pendidikan yang baru.

Borg dan Gall (dalam Ghufron, 2005: 1) mengajukan serangkaian tahap yang harus ditempuh dalam pendekatan ini, yaitu "research and information collecting, planning, develop preliminary form of product, preliminary field testing, main product revision, main field testing, operational product revision, operational field testing, final product revision, and dissemination and implementation". Apabila langkah-langkah tersebut diikuti dengan benar, diasumsikan menghasilkan suatu produk pembelajaran yang siap pakai.

Research and information collecting. Tahap ini bisa dikatakan sebagai tahap studi pendahuluan. Dalam tahap ini, kegiatan-kegiatan yang dilakukan adalah melakukan studi pustaka yang melandasi produk pembelajaran yang akan dikembangkan, obeservasi di kelas, dan merancang kerangka kerja penelitian dan pengembangan produk pembelajaran (Ghufron, 2005: 1).

Planning. Setelah studi pendahuluan dilakukan, langkah berikutnya adalah merancang berbagai kegiatan dan prosedur yang akan ditempuh dalam penelitian dan pengembangan produk pembelajaran. Kegiatan-kegiatan yang perlu dilakukan dalam tahap ini, yaitu merumuskan tujuan khusus yang ingin dicapai dengan dikembangkannya suatu produk; memperkirakan dana, tenaga, dan waktu yang diperlukan untuk mengembangkan suatu produk; merumuskan kemampuan peneliti, prosedur kerja, dan bentuk-bentuk partisipasi yang diperlukan selama penelitian dan pengembangan suatu produk; dan merancang uji kelayakan (Ghufron, 2005: 1).

Development of the preliminary form of the product. Tahap ini merupakan tahap perancangan draf awal produk pembelajaran yang siap diujicobakan, termasuk di dalamnya sarana dan prasarana yang 
diperlukan untuk uji coba dan validasi produk, alat evaluasi, dan lain-lain (Ghufron, 2005: 1).

Preliminary field test and product revision. Tujuan dari tahap ini adalah memperoleh deskripsi latar (setting) penerapan atau kelayakan suatu produk jika produk tersebut benar-benar telah dikembangkan. Uji coba pendahuluan ini bersifat terbatas. Hasil uji coba terbatas ini dipakai sebagai bahan untuk melakukan revisi terhadap suatu produk yang hendak dikembangkan. Pelaksanaan uji coba terbatas bisa berulang-ulang hingga diperoleh draft produk yang siap diujicobakan dalam skop yang lebih luas (Ghufron, 2005: 1).

Main field test and product revision. Tahap ini biasanya disebut sebagai uji coba utama dengan skop yang lebih luas. Tujuan dari tahap ini adalah menentukan apakah suatu produk yang hendak dikembangkan benar-benar telah menunjukkan suatu performansi sebagaimana yang diharapkan. Untuk mencapai tujuan tersebut, biasanya tahap ini menggunakan rancangan penelitian eksperimen. Hasil dari uji coba utama dipakai untuk merevisi produk tersebut hingga diperoleh suatu produk yang siap untuk divalidasi (Ghufron, 2005: 1).

Operational field test and final product revision. Tujuan dari tahap ini adalah untuk menentukan apakah suatu produk yang dikembangkan itu benarbenar siap dipakai di sekolah tanpa melibatkan kehadiran peneliti atau pengembang produk. Pada umumnya, tahap ini disebut sebagai tahap uji validasi model (Ghufron, 2005: 1).

Dissemination and implementation. Tahap ini ditempuh dengan tujuan agar produk yang baru saja dikembangkan itu bisa dipakai oleh masyarakat luas. Inti kegiatan dalam tahap ini adalah melakukan sosialisasi terhadap produk hasil pengembangan. Misalnya, melaporkan hasil dalam pertemuanpertemuan profesi dan dalam bentuk jurnal ilmiah.

\section{Hakikat Belajar Mandiri}

Belajar mandiri tidak berarti belajar sendiri. Hal yang terpenting dalam proses belajar mandiri ialah peningkatan kemauan dan keterampilan siswa dalam proses belajar tanpa bantuan orang lain, sehingga pada akhirnya siswa tidak tergantung pada pendidik/ instruktur, pembimbing, teman, atau orang lain dalam belajar. Dalam belajar mandiri, siswa akan berusaha sendiri dahulu untuk memahami isi pelajaran yang dibaca atau dilihatnya melalui media audio visual. Kalau mendapat kesulitan barulah bertanya atau mendiskusikannya dengan teman, pendidik/ instruktur atau orang lain. Siswa yang mandiri akan mampu mencari sumber belajar yang dibutuhkannya.
Proses belajar mandiri memberi kesempatan peserta didik untuk mencerna materi ajar dengan sedikit bantuan pendidik. Mereka mengikuti kegiatan belajar dengan materi ajar yang sudah dirancang khusus sehingga masalah atau kesulitan belajar sudah diantisipasi sebelumnya. Model belajar mandiri ini sangat bermanfaat, karena dianggap luwes, tidak mengikat serta melatih kemandirian peserta didik agar tidak bergantung atas kehadiran atau uraian materi ajar dari pendidik. Berdasarkan gagasan keluwesan dan kemandirian inilah belajar mandiri telah ber'metamorfosis' sedemikian rupa, diantaranya menjadi sistem belajar terbuka dan belajar jarak jauh. Perubahan tersebut juga dipengaruhi oleh ilmu-ilmu lain dan kenyataan di lapangan (Prawiradilaga, 2004 :193)

Sistem belajar mandiri menuntut adanya materi ajar yang dirancang khusus untuk itu. Menurut Prawiradilaga (2004:194) Beberapa syarat yang harus dipenuhi oleh materi ajar ini, sebagai berikut.

1). Kejelasan rumusan tujuan belajar (umum dan khusus).

2). Materi ajar dikembangkan setahap demi setahap, dikemas mengikuti alur desain pesan, seperti keseimbangan pesan verbal dan visual.

3). Materi ajar merupakan sistem pembelajaran lengkap, yaitu ada rumusan tujuan belajar, materi ajar, contoh/bukan contoh, evaluasi penguasaan materi, petunjuk belajar dan rujukan bacaan.

4). Materi ajar dapat disampaikan kepada peserta didik melalui media cetak, atau komputerisasi seperti CBT, CD-ROM, atau program audio/video.

5). Materi ajar itu dikirim dengan jasa pos, atau menggunakan teknologi canggih dengan internet (situs tertentu) dan e-mail; atau dengan cara lain yang dianggap mudah dan terjangkau oleh peserta didik.

6). Penyampaian materi ajar dapat pula disertai program tutorial, yang diselenggarakan berdasarkan jadwal dan lokasi tertentu atau sesuai dengan kesepakatan bersama.

\section{METODOLOGI PENELITIAN}

\section{Tujuan Penelitian}

Penelitian ini bertujuan untuk mengembangkan bahan ajar cetak (modul) pada mata kuliah Perkembangan Anak Usia SD sebagai sarana belajar mandiri mahasiswa PGSD FIP UNJ.

\section{Tempat dan Waktu Penelitian}

Penelitian dilakukan di PGSD FIP UNJ pada mata kuliah Perkembangan Anak Usia SD. Pelaksanaan penelitian dilakukan pada semester ganjil 
tahun 2010/2011.

\section{Objek Penelitian}

Objek penelitian adalah bahan ajar cetak berupa modul mata kuliah Perkembangan Anak Usia SD dan Filsafat Pendidikan.

\section{Metode Penelitian}

Metode penelitian yang akan digunakan yaitu metode Research and Development ( $\mathrm{R} \& \mathrm{D})$ dari Borg dan Gall. Alur rancangan R\&D yang akan dilakukan pada dua mata kuliah, adalah sebagai berikut.

\section{Research and information collecting}

Pada tahap ini, penelitian akan bermula dari penelitian pendahuluan sederhana dan pengumpulan data awal berupa hasil wawancara peneliti terhadap beberapa mahasiswa mata kuliah PAUSD mengenai kendala yang dihadapi di mata kuliah PAUSD. Setelah dilakukan pencarian data awal barulah peneliti melakukan penyusunan proposal penelitian.

\section{Planning}

Pada tahap ini, dilakukan perencanaan silabus perkuliahan, analisis silabus perkuliahan untuk menentukan materi dalam bahan ajar, dan perencanaan pembuatan produk bahan ajar mata kuliah Perkembangan Anak Usia SD. Dalam hal ini berkaitan dengan pembuatan Rencana Pelaksanaan Kegiatan Program Semester (RPKPS).

3. Development of the preliminary form of the product

Pada tahap ini, dilakukan pembuatan bahan ajar mata kuliah Perkembangan Anak Usia SD sebagai pembuatan produk awal bahan ajar.

\section{Preliminary field test and product revision}

Tahap ini merupakan uji coba awal yang dilakukan dengan cara evaluasi teman sejawat dan evaluasi pakar. Evaluasi teman sejawat terdiri dari tiga orang pengajar mata kuliah Perkembangan Anak Usia SD baik yang saat ini sedang mengajar atau yang telah mengajar di semester lalu. Kemudian, evaluasi pakar dilakukan oleh pakar yang bergelar profesor ke SD-an berjumlah satu orang dan bergelar doktor sebanyak dua orang untuk mata kuliah Perkembangan Anak Usia SD.

\section{Main field test and product revision}

Revisi produk pada tahap ini dilakukan setelah mendapatkan koreksi dari evaluasi teman sejawat dan pakar berkaitan dengan isi bahan ajar.

6. Operational field test and final product revision

Pada tahap ini dilakukan dua uji coba lapangan yaitu uji coba kecil pada 10 mahasiswa mata kuliah Perkembangan Anak Usia SD yang kemudian dilakukan perbaikan. Setelah itu, uji coba lapangan 2 adalah uji coba kelompok besar pada 30 mahasiswa
(10 mahasiswa pada uji coba kecil tidak dilibatkan lagi) mata kuliah Perkembangan Anak Usia SD. Kemudian, dilakukan perbaikan kembali untuk bahan ajar. Setelah selesai perbaikan, bahan ajar dianggap telah sempurna.

\section{Dissemination and implementation}

Tahap ini dilakukan diseminasi untuk mengebarkan atau mengomunikasikan produk yang sudah dikembangkan. Namun, dalam penelitian ini, tahap ini tidak akan dilakukan dengan pertimbangan waktu, tenaga, dan biaya.

\section{Populasi Penelitian}

Dalam penelitian ini digunakan populasi seluruh mahasiswa mata kuliah Perkembangan Anak Usia SD dan Filsafat Pendidikan semester genap tahun 2009/2010. Mahasiswa mata kuliah Perkembangan Anak Usia SD terdiri dari 48 mahasiswa. Karakteristik mahasiswa mata kuliah Perkembangan Anak Usia SD, sebagai berikut.

1) Terdiri dari mahasiswa alih program yang sudah mengajar

2) Lulus dari program D-2 PGSD

3) Usia berkisar 23-30 tahunan

4) Lebih sering mengaitkan materi dengan kasus di tempat mengajar

\section{Sampel Penelitian}

Untuk uji coba awal melibatkan 3 orang dosen baik untuk evaluasi sejawat maupun evaluasi pakar. Uji lapangan 1 dilakukan kepada 10 mahasiswa mata kuliah Perkembangan Anak Usia SD dan 10 mahasiswa Filsafat Pendidikan. Mahasiswa tersebut berasal dari mahasiswa yang memiliki kemampuan sedang, di atas sedang, dan di bawah sedang. Uji coba lapangan 1 dimaksudkan untuk mendapatkan komentar tentang isi atau materi pelajaran yang ada dalam bahan ajar.

Peneliti pada uji coba lapangan 1 mengajak mahasiswa membaca bahan ajar dan mendiskusikan tentang isi bahan ajar dan tes yang termuat di dalamnya. Peneliti mencatat komentar mahasiswa dan menyimpulkannya sebagai perbaikan bahan ajar. Selain itu, pada uji lapangan 1, mahasiswa diberikan tes keterbacaan bahan ajar sebelum dijadikan instrument untuk uji lapangan 2.

Setelah direvisi, dilakukan uji coba lapangan 2 kepada 30 mahasiswa masing-masing mata kuliah Perkembangan Anak Usia SD dan Filsafat Pendidikan. Di antara mahasiswa tersebut tidak termasuk tiga mahasiswa yang telah ikut dalam uji coba lapangan 1. Dalam uji coba lapangan 2, mahasiswa diberikan tes keterbacaan bahan ajar dan penguasaan materi pelajaran yang ada di bahan ajar. 


\section{Instrumen dan Pengumpulan Data}

Pengumpulan data dilakukan dengan wawancara mendalam (in depth interview) menggunakan pertanyaan open-ended untuk evaluasi teman sejawat dan pakar. Menggunakan alat rekam (tape-recorder) untuk mengingat hasil wawancara.

Mahasiswa untuk uji coba lapangan 2 dilakukan tes tingkat keterbacaan bahan ajar dan tes pilihan ganda, sebagai berikut:

1) Metode tes tingkat keterbacaan bahan ajar menggunakan metode tes rumpang, metode tes rumpang digunakan untuk mengetahui tingkat keterbacaan teks bahan ajar sehingga diperoleh informasi bahwa bahan ajar tersebut mudah dipahami atau tidak.

2) Metode tes pilihan ganda. Metode tes pilihan ganda dilakukan untuk mengetahui tingkat penguasaan materi dari mahasiswa yang telah mempelajari bahan ajar secara mandiri.

Instrumen penelitian yang digunakan untuk mengukur tingkat keterbacaan digunakan prosedur cloze test (tes rumpang) yang dikembangkan oleh Taylor (1953) adalah sejenis tes dalam bentuk wacana dengan sejumlah kata yang dikosongkan (rumpang) dan pengisi tes diminta mengisi kata-kata yang sesuai di tempat yang dikosongkan itu (Sitepu, 2006: 131).

Dalam bahan ajar mata kuliah Perkembangan Anak Usia SD yang akan dijadikan tes rumpang adalah kegiatan belajar di awal, tengah, dan akhir. Dikarenakan bahan ajar mata kuliah Perkembangan Anak Usia SD terdiri dari delapan kegiatan belajar, maka yang dijadikan tes rumpang yaitu kegiatan belajar 1, 4, dan 8 . Sedangkan, bahan ajar mata kuliah Filsafat Pendidikan terdiri dari tujuh kegiatan belajar, maka yang dijadikan tes rumpang yaitu kegiatan belajar 1, 4, dan 7 .

Instrumen untuk tes pilihan ganda dilakukan guna mengukur tingkat pemahaman, karena tes objektif dipandang dapat mengungkap tingkat penguasaan siswa terhadap materi bahan ajar yang telah dipelajari.

Jumlah butir tes bahan ajar mata kuliah Perkembangan Anak Usia SD adalah 20 soal yang mencakup tidak seluruh materi pokok mata kuliah Perkembangan Anak Usia SD seperti yang terdapat dalam bahan ajar yang disusun oleh peneliti. Waktu yang diberikan adalah 30 menit. Sedangkan, jumlah butir tes bahan ajar mata kuliah Filsafat Pendidikan adalah 20 soal yang juga tidak mencakup seluruh materi pokok mata kuliah Filsafat Pendidikan seperti yang terdapat dalam bahan ajar yang disusun oleh peneliti. Waktu yang diberikan adalah 30 menit.

\section{Analisis Data}

Instrumen tes tingkat keterbacaan bahan ajar diambil dari teks bahan ajar Perkembangan Anak Usia SD. Digunakan tes cloze (test rumpang) karena bentuk tes cloze sama dan tidak dapat diubah karena harus mengambil bacaan asli sehingga tes cloze tidak memerlukan analisis butir tes.

Tes tingkat keterbacaan teks bahan ajar digunakan rumus :

$$
x=\frac{\sum x_{1}}{n} \times 100 \%
$$

Keterangan:

$$
\begin{aligned}
\sum X_{1} & =\text { Jumlah soal yang benar } \\
\mathrm{n} & =\text { Jumlah soal (Zaenudin, 2005: 29) }
\end{aligned}
$$

Hasil terakhir selanjutnya dibandingkan dengan kriteria sebagai berikut.

\begin{tabular}{||l|l||}
\hline \multicolumn{1}{|c|}{$\begin{array}{l}\text { Jumlah kata } \\
\text { yang benar }\end{array}$} & \multicolumn{1}{|c|}{ Tingkat kesulitan } \\
\hline a. $>50 \%$ & $\begin{array}{l}\text { "Mudah" dalam arti pembaca } \\
\text { mengerti isi bacaan } \\
\text { "Agak sukar" dalam arti } \\
\text { pembaca memerlukan bantuan } \\
\text { untuk mengerti isi bacaan } \\
\text { "Sangat sukar" dalam arti } \\
\text { pembaca tidak } \\
\text { memahami isi bacaan (Sitepu, } \\
\text { 2006: 133) }\end{array}$ \\
c. $>35 \%-50 \%$ & \\
\hline
\end{tabular}

Untuk analisis data tes pilihan ganda, sebelum soal-soal tes pilihan ganda digunakan sebagai instrumen penelitian, maka soal - soal tersebut perlu dilakukan analisis untuk mengetahui validitas, reliablitas, tingkat kesukaran, dan daya beda soal.

Teknik analisis instrument yang digunakan adalah sebagai berikut :

a) Validitas

Dalam penelitian ini rumus yang digunakan untuk menentukan validitas adalah :

$$
r_{x y}=\frac{N \sum X Y-\left(\sum X\right)\left(\sum Y\right)}{\sqrt{\left\{\left(\mathrm{N} \sum \mathrm{X}^{2}-\left(\sum \mathrm{X}\right)^{2}\left(\mathrm{~N} \sum \mathrm{Y}^{2}-\left(\sum \mathrm{Y}\right)^{2}\right)\right.\right.}}
$$

Keterangan :

$$
\begin{array}{ll}
r_{x y} & =\text { Koefisien korelasi antara } \mathrm{X} \text { dan } \mathrm{Y} \\
\mathrm{N} & =\text { Jumlah peserta tes } \\
\sum \mathrm{X} & =\text { Jumlah skor yang menjawab benar } \\
\sum \mathrm{Y} & =\text { Jumlah skor total } \\
\sum \mathrm{XY} & =\text { Jumlah skor yang menjawab benar dikalikan } \\
& \text { dengan skor tes (Zaenudin, 2005: 29) } \\
& \text { Harga } r_{x y} \text { yang diperoleh tiap - tiap soal } \\
\text { dikonsultasikan dengan harga tabel product moment. }
\end{array}
$$


Apabila > r tabel, maka item soal dikatakan valid, tetapi jika < r tabel, maka item dikatakan tidak valid. Dalam penelitian ini digunakan taraf signifikan $5 \%$.

b) Reliabilitas

Dalam penelitian ini, rumus yang digunakan untuk menentukan reliabilitas adalah rumus:

$$
r_{11}=\left(\frac{k}{k-1}\right)\left(\frac{V_{t}-\sum p q}{V_{t}}\right)
$$

\section{Keterangan}

$r_{11} \quad=$ Reliabilitas instrumen

$\mathrm{K}$ = Banyaknya butir soal

$V_{t} \quad=$ Variant total

$\mathrm{p} \quad=$ =Proporsi subjek yang menjawab betul dalam satu kolom

$\mathrm{q} \quad=$ Proporsi subjek yang menjawab salah dalam satu kolom

$\mathrm{q} \quad=1-\mathrm{p}$ (Zaenudin, 2005: 30)

Harga $r_{11}$ yang diperoleh tiap - tiap soal dikonsultasikan dengan harga tabel product moment. Apabila $r_{11}>\mathrm{r}$ tabel, maka perangkat tes dikatakan reliable, tetapi jika < r table, perangkat tes dikatakan belum reliable. Dalam penelitian ini digunakan taraf signifikan $5 \%$.

c) Taraf Kesukaran Soal (P)

Soal yang baik adalah soal yang tidak terlalu mudah dan tidak terlalu sukar.

$$
P=\frac{B}{J S}
$$

Keterangan :

$\mathrm{P}=$ Indeks Kesukaran

$\mathrm{B}=$ Siswa yang menjawab benar

JS = Jumlah peserta tes

Dengan indeks kesukaran :

$0,00 \leq \mathrm{P}<0,30=$ sukar

$0,30 \leq \mathrm{P}<0,70=$ sedang

0,70 $\leq \mathrm{P}<1,00=$ mudah (Zaenudin, 2005: 31)

d) Daya Pembeda Soal

Daya pembeda soal adalah kemampuan suatu soal untuk membedakan antara mahasiswa yang pandai (berkemampuan tinggi) dengan siswa yang kurang pandai, rumus untuk menentukan indeks Daya Pembeda Soal adalah sebagai berikut

$$
D=P A-P B ; P A=\frac{B A}{J A} ; P B=\frac{B B}{J B}
$$

Keterangan:

$\mathrm{D}$ = daya beda soal

$\mathrm{J}=$ jumlah peserta tes

$\mathrm{JA}=$ banyaknya peserta kelompok atas

$\mathrm{JB}$ = banyaknya kelompok bawah
$\mathrm{BA}=$ banyaknya peserta kelompok atas yang menjawab soal dengan benar

$\mathrm{BB}$ = banyaknya peserta kelas bawah yang menjawab benar (Zaenudin, 2005: 31) .

Klasifikasi daya pembeda:

$0,00 \leq \mathrm{D}<0,20=$ jelek

$0,20 \leq \mathrm{D}<0,40=$ cukup

$0,40 \leq \mathrm{D}<0,70=$ baik

$0,70 \leq \mathrm{D}<1,00=$ baik sekali (Zaenudin, 2005: 31 )

Setelah itu, untuk menghitung hasil penguasaan materi mahasiswa dalam bahan ajar Perkembangan Anak Usia SD maupun Filsafat Pendidikan digunakan rumus:

$$
\mathrm{NP} \%=\frac{n}{N} \times 100 \%
$$

(Yamin, 2007: 160)

Keterangan:

$\mathrm{NP} \%=$ persentase nilai siswa yang diperoleh

$\mathrm{N} \quad=$ jumlah skor total

n = jumlah skor yang diperoleh

Dengan kriteria sebagai berikut:

Hasil $\leq 40 \%$ : kemampuan kurang sekali

$40 \%<$ hasil $\leq 50 \%$ : kemampuan kurang

$50 \%<$ hasil $\leq 60 \%$ : kemampuan sedang

$60 \%<$ hasil $\leq 80 \%$ : kemampuan baik

Hasil $>80 \%$ : kemampuan baik sekali

\section{HASIL DAN PEMBAHASAN}

\section{Deskripsi data}

Deskripsi data akan menjelaskan mengenai tiga hal yaitu evaluasi dari teman sejawat dan pakar, hasil tes tingkat keterbacaan bahan ajar, serta hasil tingkat penguasaan materi bahan ajar mata kuliah PAUSD.

Berdasarkan evaluasi teman sejawat untuk bahan ajar mata kuliah PAUSD ditemukan bahwa hendaknya bahan ajar memasukkan materi-materi yang pada awalnya belum dimasukkan ke dalam bahan ajar misal tentang pendidikan karakteri di SD. Dengan pertimbangan bahwa saat ini, pendidikan karakter sedang disosialisasikan oleh pemerintah menjadi terintegrasi dalam semua mata pelajaran di sekolah. Dengan demikian, peneliti memasukkan materi pendidikan karakter ke dalam bahan ajar PAUSD.

Berdasarkan evaluasi pakar untuk bahan ajar PAUSD ditemukan bahwa hendaknya dalam materi perkembangan kognitif melihat pada teori Piaget karena sebagai landasan dalam memahami perkembangan kognitif siswa SD. Dengan demikian, peneliti mengambil materi perkembangan kognitif 
siswa SD dari sudut pandang Piaget.

Tingkat keterbacaan teks bahan ajar mata kuliah PAUSD dilakukan untuk mengetahui sampai sejauh mana atau pada kategori apakah teks bahan ajar dapat dipahami oleh mahasiswa. Tes keterbacaan ini penting untuk dilakukan mengingat bahwa mahasiswa adalah user dari bahan ajar ini. Di samping itu, bahan ajar ini bersifat mandiri sehingga ketergantungan bimbingan dari dosen diharapkan dapat digantikan oleh bahan ajar ini meskipun tetap tidak bisa untuk meniadakan peran dosen karena bahan ajar ini sebagai pendukung atau salah satu sumber belajar yang dirancang oleh dosen untuk membantu dalam kegiatan belajar dan membelajarkan.

1. Uji lapangan 1

Dilakukan dengan tes keterbacaan melalui pengambilan sampel untuk kegiatan belajar yang diteliti terdiri dari 3 kegiatan belajar. Dengan asumsi kegiatan belajar yang diambil adalah awal, tengah, dan akhir yaitu kegiatan belajar 1, 4, dan 8 .

Dari hasil penghitungan diperoleh bahwa keterbacaan pada bahan ajar PAUSD, kegiatan belajar 1 mudah dipahami karena memiliki nilai rata-rata 63.31\%. Hal ini berdasarkan kriteria keterbacaan (dalam Sitepu, 2006: 133) yaitu > 50\% “Mudah" dalam arti mahasiswa memahami isi bacaan. Sedangkan di kegiatan belajar 4, hasil tes keterbacaan menunjukkan mudah dipahami oleh mahasiswa karena memiliki nilai rata-rata $58.75 \%$. Lalu, untuk kegiatan belajar 8 diperoleh hasil tes keterbacaan yaitu $57.18 \%$ yang menunjukkan mahasiswa memahami isi bacaan.

2. Uji lapangan 2

Dalam uji lapangan 2, dilakukan kembali tes keterbacaan dengan responden mahasiswa sebanyak 30 orang. Dari hasil penghitungan diperoleh bahwa keterbacaan pada bahan ajar PAUSD, kegiatan belajar 1 mudah dipahami karena memiliki nilai rata-rata $63.26 \%$. Hal ini menandakan bahwa mahasiswa memahami isi bacaan. Sedangkan di kegiatan belajar 4, hasil tes keterbacaan menunjukkan mudah dipahami oleh mahasiswa karena memiliki nilai ratarata $55.92 \%$. Lalu, untuk kegiatan belajar 8 diperoleh hasil tes keterbacaan yaitu $61.03 \%$ yang menunjukkan mahasiswa memahami isi bacaan.

Selain tes keterbacaan, dilakukan tes penguasaan materi untuk melihat kemampuan mahasiswa dalam menguasai materi-materi yang diberikan. Dari hasil penghitungan diperoleh bahwa kemampuan mahasiswa dalam menguasai materi bahan ajar PAUSD adalah "Baik" dibuktikan dnegan perolehan rata-rata skor mencapai $62.33 \%$.

\section{Pembahasan}

Berdasarkan hasil deskripsi data di atas, diperoleh gambaran bahwa bahan ajar Perkembangan Anak Usia SD memiliki tingkat keterbacaan yang mudah dipahami serta penguasaan materi oleh mahasiswa dinilai baik. Besar kecilnya tingkat keterbacaan teks dari bahan ajar tergantung pada panjang pendeknya kalimat yang digunakan, struktur bahasa dan juga penggunaan bahasa sebagai media komunikasi antara penulis dan pemakai.

Bahan ajar yang dibuat telah melalui prinsipprinsip instruksional yang disarankan, dimulai dari melakukan sebuah analisis instruksional, silabus, hingga menjadi sebuah bahan ajar. Dengan kemudahan dalam memahami kedua bahan ajar yang dibuat menunjukkan dampak positif bagi pendidik (dalam hal ini peneliti) yaitu akan mempunyai lebih banyak waktu untuk membimbing peserta didik dalam proses pembelajaran, membantu peserta didik untuk memperoleh pengetahuan baru dari segala sumber atau referensi yang digunakan dalam bahan ajar, dan peranan pendidik sebagai satu-satunya sumber pengetahuan menjadi berkurang

Bahan ajar ini sengaja dibuat dalam bentuk modul untuk konsep belajar mandiri bagi mahasiswa karena pada hakikatnya mahasiswa memiliki kemampuan untuk bekerja sendiri dan lebih bertanggung jawab atas tindakan-tindakannya. Dikarenakan bahan ajar ini berbentuk modul, maka memiliki beberapa karakteristik yaitu pertama, self instructional karena membuat mahasiswa mampu membelajarkan diri sendiri dengan bahan ajar dua mata kuliah yang dikembangkan. Untuk memenuhi karakter self instructional, maka di dalam modul diberikan tujuan yang dirumuskan dengan jelas, baik tujuan umum (standar kompetensi) maupun tujuan khusus (kompetensi dasar). Kegiatan belajar yang disajikan dalam bahan ajar pun dikemas ke dalam unit-unit atau kegiatan yang lebih spesifik seperti kegiatan belajar $1, \ldots .$. dst. Dalam akhir setiap kegiatan belajar diberikan evaluasi untuk mengukur ketercapaian tujuan yang ingin dicapai di setiap kegiatan belajar.

Kedua, self contained karena seluruh materi pelajaran dari satu unit kompetensi atau subkompetensi yang dipelajari terdapat di dalam satu bahan ajar secara utuh.

Ketiga, stand alone (berdiri sendiri) karena kedua bahan ajar bagi mahasiswa tidak tergantung pada bahan ajar lain atau tidak harus digunakan bersamasama dengan bahan ajar lain. Mahasiswa sudah dapat memahami isi dari bahan ajar yang dimaksud, hal ini dibuktikan dengan tes keterbacaan yang telah 
dilakukan.

Keempat, adaptive yaitu bahan ajar memiliki daya adaptif yang tinggi terhadap perkembangan ilmu dan teknologi dibuktikan dengan penggunaan buku-buku acuan yang dijadikan sumber rujukan dalam penyusunan bahan ajar merupakan sumber-sumber yang up to date.

Kelima, user friendly yaitu setiap instruksi dan paparan informasi yang tampil bersifat membantu dan bersahabat dengan pemakainya, sehingga mahasiswa dapat memahaminya dengan baik.

Proses belajar mandiri diadakan bagi mahasiswa dengan harapan ketika datang ke kelas, mahasiswa sudah memiliki konsep awal tentang pengetahuan yang akan dipelajari. Di sini, peneliti (sebagai dosen) berusaha untuk menanamkan sebuah konsep konstruktivisme dalam proses belajar mahasiswa yaitu mahasiswa diminta mengkonstruksi sebuah pengetahuan secara mandiri lalu tugas dosen adalah membimbing pengetahuan yang telah dibentuk mahasiswa ke arah yang tepat.

Mahasiswa dalam belajar mandiri mengikuti kegiatan belajar dalam materi bahan ajar yang sudah dirancang khusus sehingga masalah atau kesulitan belajar sudah diantisipasi sebelumnya. Model belajar mandiri ini sangat bermanfaat, karena dianggap luwes, tidak mengikat serta melatih kemandirian mahasiswa agar tidak bergantung atas kehadiran atau uraian materi ajar dari dosen.

\section{PENUTUP}

\section{Kesimpulan}

Berdasarkan hasil penelitian yang telah dilakukan maka dapat ditarik kesimpulan, bahwa bahan ajar PAUSD dilihat berdasarkan atas dua faktor yaitu tingkat keterbacaan dan pemahaman mahasiswa dalam menguasai materi bahan ajar.

Berdasarkan tingkat keterbacaan, bahan ajar Perkembangan Anak Usia SD memiliki nilai 55-63\% dari tiga macam kegiatan belajar yang telah diujikan. Dengan nilai tersebut, dapat diambil kesimpulan bahwa bahan ajar mudah dipahami oleh mahasiswa.

Penguasaan materi bahan ajar Perkembangan Anak Usia SD, mahasiswa mencapai nilai 62,33\% yang berarti baik dalam menguasai materi dengan tingkat kesulitan dari yang sedang hingga mudah serta daya beda soal pun baik dan baik sekali.

Saran

Berdasarkan hasil penelitian, maka dapat diajukan beberapa saran, yaitu (1) diperlukan adanya pengembangan yang selalu dilakukan untuk menyempurnakan bahan ajar ini dalam rangka pembelajaran yang berkelanjutan; (2) hendaknya pengguna bahan ajar ini diberikan waktu yang lebih banyak untuk menguasai bahan ajar; (3) rekomendasi penelitian selanjutnya yaitu setelah dilakukan metode R\&D, dapat dilibatkan kembali metode penelitian eksperimen untuk mengetahui apakah bahan ajar yang dibuat memiliki pengaruh yang cukup signifikan misal dalam hasil belajar mahasiswa; dan (4) para peneliti berikutnya perlu mempertimbangkan keterbatasan dalam penelitian ini sehingga dapat menjadi rekomendasi untuk penelitian-penelitian selanjutnya.

\section{DAFTAR PUSTAKA}

Eriyadi, S. (2008). Community: Surat pembaca: Merangsang kreativitas guru menyusun bahan ajar. Diakses tanggal 03 Mei 2010 dari http:// www.radarsema-rang.com/community / artikeluntukmu-guru-ku/2259-merangsangkreativitas-guru-menyusun-bahan-ajar.html

Ghufron, A. (2005). Model pengembangan sistem pembelajaran bagi penyiapan sumberdaya manusia era informasi. Diakses tanggal 03 Mei 2010 dari http://www.teknologipendidikan.net

Mulyasa, E. (2006). Kurikulum berbasis kompetensi. Bandung: PT. Remaja Rosdakarya.

Prawiradilaga, D.S. \& Siregar, E. (2004). Mozaik teknologi pendidikan. Penyunting: Dewi Salma Prawiradilaga. "Fenomena belajar mandiri". Jakarta: Kencana

Sitepu, B.P. (2006). Penyusunan buku pelajaran. Jakarta: Verbum Publishing.

Sudjana, N. \& Rivai, A. (2003). Teknologi pengajaran. Bandung: Sinar Baru Algesindo.

Sudrajat, A. (2008). Pengembangan bahan ajar. Diakses tanggal 03 Mei 2010 dari http:// akhmadsudrajat.word-press.com/2008/01/ 24/download-pengembangan-bahan-ajar/

Widodo, C.S. \& Jasmadi. (2008). Panduan menyusun bahan ajar berbasis kompetensi. Jakarta: PT Elex Media Komputindo

Zaenudin. (2005). Pengembangan bahan ajar fisika menggunakan komputer berbasis web pada mata kuliah fisika sekolah menengah pokok bahasan listrik statis. Skripsi. Diakses tanggal 03 Mei 2010 dari http://digilib.unnes.ac.id/gsdl/collect/ skripsi/archives/HASH01fd/66d4a-05d.dir/ doc.pdf 


\section{KETERANGAN PENULIS}

Kasina Ahmad, lahir pada tanggal 1 Mei 1949. Saat ini menjabat sebagai Ketua Jurusan Pendidikan Guru Sekolah Dasar Fakultas Ilmu Pendidikan Universitas Negeri Jakarta.
Ika Lestari, lahir pada tanggal 27 Februari 1984. Saat ini menjabat sebagai dosen Jurusan Pendidikan Guru Sekolah Dasar Fakultas Ilmu Pendidikan Universitas Negeri Jakarta. 